\title{
Persepsi Masyarakat Mengenai Prioritas Pembangunan Infrastruktur Desa Berbasis Mitigasi Bencana (Studi Kasus Nagari/Desa Inderapura Selatan)
}

\author{
People Perception on Village Infrastructure Development Priorities \\ based on Disaster Mitigation (Case Study: Inderapura Selatan Village)
}

\author{
Anggraini Rasadi ${ }^{1, a)}$, Benny Hidayat ${ }^{2, b)}$ \& Taufika Ophiyandri ${ }^{2, c)}$ \\ ${ }^{1)}$ Mahasiswa Magister Teknik Sipil, Universitas Andalas, Padang. \\ ${ }^{2)}$ Dosen Jurusan Teknik Sipil,Universitas Andalas, Padang. \\ Koresponden : ${ }^{a}$ anggraini.rasadi@ gmail.com, ${ }^{b}$ bennyhidayat@eng.unand.ac.id \& \\ ${ }^{c}$ t.ophiyandi@gmail.com
}

\begin{abstract}
ABSTRAK
Bencana merupakan masalah global saat ini. Khususnya di Indonesia, Perspektif penanggulangan bencana telah memasuki paradigma baru, dari sebelumnya hanya terfokus pada kegiatan tanggap darurat saja, kini juga memakai pendekatan mitigasi dan kesiapsiagaan. Mitigasi dan kesiapsiagaan dilakukan pada saat tidak terjadi bencana. Mitigasi atau penanggulangan bencana perlu dipadukan dengan upaya-upaya pengurangan risiko bencana kedalam pembangunan demi keberlanjutan serta pengarusutamaan pengurangan risiko bencana ke dalam perencanaan program dan kegiatan desa. Dengan kata lain analisis risiko bencana harus menjadi salah satu dasar dalam perencanan pembangunan yang berkelanjutan. Pembangunan sarana dan prasarana untuk penanggulangan bencana juga merupakan salah satu prioritas pembangunan desa. Dalam penelitian ini dilakukan teknik pengambilan data berupa kuesioner untuk mengetahui bagaimana persepsi masyarakat mengenai perencanaan pembangunan infrastruktur yang berdasarkan bencana. Seluruh responden setuju untuk memasukkan aspek kebencanaan sebagai salah satu pertimbangan dalam merangking program kegiatan pembangunan infrastruktur desa. Namun, perencanaan pembangunan infrastruktur desa yang telah dilaksanakan belum mempertimbangkan aspek penanggulangan bencana.
\end{abstract}

Kata Kunci : manajemen infrastruktur, mitigasi bencana, infrastruktur desa, prioritas pembangunan

\section{PENDAHULUAN}

Mitigasi bencana perlu dimasukkan sebagai salah satu aspek dalam pengambilan keputusan dan perangkingan kegiatan pembangunan infrastruktur desa. Pengurangan risiko bencana berbasis masyarakat diarahkan agar menjadi bagian terpadu dari rencana dan kegiatan pembangunan rutin, serta menjadi bagian dari kebijakan-kebijakan sektoral. Begitu pula sebaliknya, setiap proses pengelolaan pembangunan harus memasukkan unsur-unsur pengurangan risiko bencana (analisis ancaman, kerentanan dan risiko serta rencana-rencana mitigasi). Pada praktiknya, pengurangan risiko bencana seharusnya mendapatkan tempat yang memadai dalam musyawarah perencanaan pembangunan di segala tingkatan, mulai dari desa sampai negara. Analisis risiko bencana harus menjadi salah satu dasar dalam perencanaan pembangunan yang berkelanjutan. Pembangunan harus dapat memenuhi kebutuhan masyarakat di masa sekarang tanpa mengurangi hak generasi mendatang dalam memenuhi kebutuhan mereka (Perka BNPB 01/12, Supayitno \& Soemitro 2018, Suprayitno \& Soemitro 2019 ). 


\section{TINJAUAN PUSTAKA}

\section{Bencana}

Bencana adalah peristiwa atau rangkaian peristiwa yang mengancam dan mengganggu kehidupan dan penghidupan masyarakat yang disebabkan, baik oleh faktor alam dan/atau non alam maupun faktor manusia sehingga mengakibatkan timbulnya korban jiwa manusia, kerusakan lingkungan, kerugian harta benda, dan dampak psikologis (UU 24/07).

Bencana merupakan pertemuan dari tiga unsur, yaitu ancaman bencana, kerentanan, dan kemampuan yang di picu oleh suatu kejadian. Hubungan ketiga unsur tersebut dapat dilihat pada persamaan (1) dibawah ini:

\section{Risiko $=$ Ancaman $\times$ Kerentanan $/$ Kemampuan}

(Sumber : Jaswadi, 2012)

Risiko terjadinya bencana berbanding lurus dengan besarnya ancaman bahaya serta kerentanan masyarakat yang terdampak bencana. Risiko bencana dapat dikurangi dengan meningkatkan kemampuan masyarakat maupun dengan mengurangi kerentanan masyarakat terhadap bencana (Suprayitno \& Soemitro 2019).

Penyelenggaraan bencana adalah serangkaian upaya yang meliputi penetapan kebijakan pembangunan yang berisiko timbulnya bencana, kegiatan pencegahan bencana, tanggap darurat, dan rehabilitasi (UU 21/07). Penanggulangan bencana pada dasarnya diselenggarakan dalam sebuah siklus berikut:

1. Pra-Bencana, yang meliputi:

a. Saat Tidak terjadi bencana

b. Situasi terdapat potensi bencana

2. Saat Tanggap Darurat

3. Pasca Bencana

\section{Mitigasi Bencana}

Mitigasi adalah serangkaian upaya untuk mengurangi risiko bencana, baik melalui pembangunan fisik maupun penyadaran dan peningkatan kemampuan menghadapi ancaman bencana (UU 24/07). Dalam Yokohama Strategy (1994), dijelaskan bahwa strategi pengurangan risiko bencana yaitu upaya-upaya untuk meredam risiko, harus dipadukan secara sistematis didalam kebijakan dan perencanaan pada program pembangunan.

Kegiatan mitigasi dapat digolongkan mejadi 2 (dua) yaitu: Mitigasi Non-Struktural (berupa peraturan, penyuluhan, dan pendidikan) dan Mitigasi Struktural (berupa bangunan dan prasarana). Pembangunan berdasarkan kebencanaan termasuk kedalam mitigasi struktural karena pembangunannya berfungsi untuk mencegah, mengamankan, dan mengurangi dampak yang ditimbulkan oleh bencana, seperti pembangunan tanggul, dam, penaham erosi pantai, bangunan tahan gempa dan sejenisnya (Perka BNPB 04/08).

Partisipasi masyarakat merupakan hal yang penting dalam merencanakan pembangunan yang berbasis kebencananaan. Dalam UU No 24 tahun 2007 dijelaskan bahwa masyarakat berhak untuk berpartisipasi dalam pengambilan keputusan terhadap kegiatan penanggulangan bencana, khususnya yang berkaitan dengan komunitasnya. Masyarakat dapat berpartisipasi dalam perencanaan penanggulanan bencana dalam rangka pengurangan risiko bencana. Penyelenggaran penanggulangan bencana dilakukan pada saat situasi tidak terjadi bencana.

\section{Perencanaan Pembangunan Infrastruktur Desa}

Perencanaan secara sederhana dapat diartikan sebagai suatu kegiatan yang dibuat untuk masa yang akan datang yang lebih baik dengan memperhatikan keadaan di masa sekarang maupun keadaan pada masa sebelumnya. Sedangkan perencanaan pembangunan adalah proses perumusan alternatif-alternatif atau keputusan-keputusan yang didasarkan pada data-data atau 
fakta-fakta yang akan digunakan sebagai bahan untuk melaksanakan suatu rangkaian kegiatan/aktifitas kemasyarakatan baik yang bersifat fisik dalam rangka pencapaian tujuan yang lebih baik (Maripah, 2017). Perencanaan pembangunan partisipatif adalah suatu bentuk perencanaan pembangunan yang melibatkan masyarakat secara aktif mulai dari identifikasi masalah, perumusan masalah, pencarian alternatif pemecahan masalah, terlibat dalam proses penyusunan hingga pada tahap implementasi dan evaluasi kegiatan (Nurcholis, H. et al. 2009).

\section{METODOLOGI}

Metode penelitian yang digunakan adalah penelitian deskriptif dengan analisis data kualitatif, yang digunakan untuk mengetahui persepsi masyarakat tentang perencanaan pembangunan infrastruktur desa berbasis mitigasi bencana.

Data diperoleh melalui teknik pengumpulan data kuesioner. Teknik analisis data dalam penelitian ini menggunakan analisis data kualitatif. Metode analisis tersebut dapat digunakan untuk mendeskripsikan persepsi masyarakat tentang perencanaan pembangunan infrastruktur desa yang berdasarkan mitigasi bencana. Penilaian kuesioner menggunakan skala Likert dengan 5 (lima) titik pilihan pada setiap butir pertanyaan yaitu sangat setuju, setuju, tidak memutuskan, tidak setuju, dan sangat tidak setuju (Likert, 1932 dalam Budiaji, 2013). Teknik sampling yang digunakan adalah convenience sampling dimana responden yang diambil berdasarkan kemudahan akses dengan asumsi bahwa target populasi homogen (Dornyei, 2007 dalam Etikan, 2015).

\section{HASIL, ANALISA DATA, DAN PEMBAHASAN}

Respoden dalam penelitian ini adalah masyarakat Nagari Inderapura Selatan yang hadir dalam Diskusi Grup Terarah/Focus Group Discussion (FGD) yaitu sebanyak 30 orang responden. Data responden seperti yang terlihat pada Tabel 1 berikut ini:

Tabel 1. Data Responden

\begin{tabular}{|c|c|c|c|c|c|}
\hline \multicolumn{2}{|c|}{ Jenis Kelamin } & \multicolumn{4}{c|}{ Pendidikan Terakhir } \\
\hline Laki-laki & Perempuan & SD & SLTP & SLTA & S1/S2 \\
\hline 14 & 16 & 1 & 2 & 17 & 10 \\
\hline $46,67 \%$ & $53,33 \%$ & $3,33 \%$ & $6,67 \%$ & $56,67 \%$ & $33,33 \%$ \\
\hline
\end{tabular}

Kuesioner dibagi dalam 3 variabel yaitu variabel pertisipasi masyarakat dalam perencanaan pembangunan, variabel perangkingan kegiatan pembangunan infrastruktur desa, dan variabel perangkingan kegiatan pembangunan infrastruktur desa berbasis mitigasi bencana. Butir pertanyaan yang ditanyakan dalam kuesioner adalah sebagai berikut : 
Tabel 2. Daftar Pertanyaan Kuesioner

\begin{tabular}{|c|c|}
\hline Kode & PERTANYAAN \\
\hline \multicolumn{2}{|c|}{ A. Partisipasi Masyarakat Dalam Perencanaan Pembangunan } \\
\hline A1 & $\begin{array}{l}\text { Apakah Bapak/Ibu hadir dalam Musyawarah Nagari Rencana Kerja Pemerintah (Musnag } \\
\text { RKP) Tahun Anggaran } 2019 \text { yang dilaksanakan di tahun 2018? }\end{array}$ \\
\hline $\mathrm{A} 2$ & $\begin{array}{l}\text { Apakah Bapak/Ibu ikut mengusulkan kegiatan pembangunan infrastruktur nagari dalam } \\
\text { Musnag RKP Tahun Anggaran 2019? }\end{array}$ \\
\hline A3 & $\begin{array}{l}\text { Apakah Bapak/Ibu ikut terlibat langsung dalam pengambilan keputusan untuk perencanaan } \\
\text { pembangunan infrastruktur RKP Tahun Anggaran 2019? }\end{array}$ \\
\hline A4 & Apakah kegiatan yang Bapak/Ibu usulkan masuk ke dalam RKP Tahun Anggaran 2019? \\
\hline \multicolumn{2}{|c|}{ B. Perangkingan Kegiatan Pembangunan Infrastruktur Desa } \\
\hline B1 & $\begin{array}{l}\text { Apakah menurut Bapak/Ibu hasil perencanaan kegiatan pembangunan infrastruktur nagari } \\
\text { tahun } 2019 \text { sudah mengakomodir kebutuhan masyarakat pada umumnya? }\end{array}$ \\
\hline B2 & $\begin{array}{l}\text { Apakah Bapak/Ibu sudah puas dengan sistem perangkingan yang digunakan dalam } \\
\text { perencanaan RKP 2019? }\end{array}$ \\
\hline B3 & $\begin{array}{l}\text { Apakah menurut Bapak/Ibu diperlukan sebuah cara/teknik perangkingan usulan } \\
\text { pembangunan infrastruktur nagari yang lebih baik dari cara perangkingan kegiatan pada } \\
\text { RKP 2019? }\end{array}$ \\
\hline B4 & $\begin{array}{l}\text { Perlukah menurut Bapak/Ibu untuk terlibat langsung dalam perangkingan kegiatan dan } \\
\text { pengambilan keputusan perencanaan pembangunan infrastruktur nagari? }\end{array}$ \\
\hline B5 & $\begin{array}{l}\text { Apakah menurut Bapak/Ibu, perangkingan kegiatan pembangunan infrastruktur nagari } \\
\text { sudah berdasarkan asas kemanfaatan? }\end{array}$ \\
\hline B6 & $\begin{array}{l}\text { Apakah menurut Bapak/Ibu, perangkingan kegiatan pembangunan infrastruktur nagari } \\
\text { sudah berdasarkan aspek partisipasi masyarakat? }\end{array}$ \\
\hline B7 & $\begin{array}{l}\text { Apakah menurut Bapak/Ibu, perangkingan kegiatan pembangunan infrastruktur nagari } \\
\text { sudah berdasarkan aspek keberlanjutan? }\end{array}$ \\
\hline B8 & $\begin{array}{l}\text { Apakah menurut Bapak/Ibu, perangkingan kegiatan pembangunan infrastruktur nagari } \\
\text { sudah memiliki kepastian pengawasan dari masyarakat? }\end{array}$ \\
\hline B9 & $\begin{array}{l}\text { Apakah menurut Bapak/Ibu, perangkingan kegiatan pembangunan infrastruktur nagari } \\
\text { sudah berdasarkan tipologi* desa/nagari? }\end{array}$ \\
\hline \multicolumn{2}{|c|}{ C. Perangkingan Berdasarkan Penanggulangan (Mitigasi) Bencana } \\
\hline $\mathrm{C} 1$ & $\begin{array}{l}\text { Apakah menurut Bapak/Ibu Penanggulangan bencana di tingkat nagari merupakan hal yang } \\
\text { penting? }\end{array}$ \\
\hline $\mathrm{C} 2$ & Perlukah menurut Bapak/Ibu untuk berpartisipasi dalam penanggulangan bencana di nagari? \\
\hline $\mathrm{C} 3$ & $\begin{array}{l}\text { Apakah menurut Bapak/Ibu perangkingan kegiatan pembangunan infrastruktur nagari tahun } \\
2019 \text { sudah berdasarkan aspek penanggulangan bencana? }\end{array}$ \\
\hline $\mathrm{C} 4$ & $\begin{array}{l}\text { Perlukah menurut Bapak/Ibu untuk memasukkan aspek penanggulangan bencana dalam } \\
\text { perangkingan kegiatan pembangunan infrastruktur nagari? }\end{array}$ \\
\hline
\end{tabular}

Variabel A menggunakan pilihan Ya dan Tidak sedangkan variabel B dan C menggunakan skala Likert dengan 5 titik pilihan pada setiap pertanyaan yaitu Sangat Tidak Setuju (STS), Tidak Setuju (TS), Netral (N), Setuju (S), dan Sangat Setuju (SS). Dari kuesioner yang sudah disebar kepada 30 orang responden, diperoleh data respon seperti yang terlihat pada tabel 3 berikut: 
Tabel 3. Data Rekap Hasil Kuesioner

\begin{tabular}{|c|c|c|c|c|c|}
\hline A. & YA & TIDAK & & & \\
\hline A1 & 26 & 4 & & & \\
\hline $\mathrm{A} 2$ & 23 & 7 & & & \\
\hline A3 & 9 & 21 & & & \\
\hline A4 & 10 & 20 & & & \\
\hline B. & STS & TS & $\mathbf{N}$ & $\mathrm{S}$ & SS \\
\hline B1 & 0 & 14 & 4 & 12 & 0 \\
\hline B2 & 0 & 25 & 3 & 2 & 0 \\
\hline B3 & 0 & 2 & 6 & 22 & 0 \\
\hline B4 & 0 & 0 & 9 & 6 & 15 \\
\hline B5 & 0 & 13 & 11 & 6 & 0 \\
\hline B6 & 0 & 19 & 7 & 4 & 0 \\
\hline B7 & 3 & 14 & 9 & 3 & 1 \\
\hline B8 & 1 & 14 & 11 & 4 & 0 \\
\hline B9 & 0 & 1 & 4 & 18 & 7 \\
\hline C. & STS & TS & $\mathbf{N}$ & $\mathbf{S}$ & SS \\
\hline $\mathrm{C} 1$ & 0 & 0 & 1 & 7 & 22 \\
\hline $\mathrm{C} 2$ & 0 & 0 & 0 & 9 & 21 \\
\hline $\mathrm{C} 3$ & 5 & 23 & 2 & 0 & 0 \\
\hline $\mathrm{C} 4$ & 0 & 0 & 2 & 16 & 12 \\
\hline
\end{tabular}

Keterangan : STS = Sangat Tidak Setuju

TS = Tidak Setuju

$\mathrm{N}=$ Netral

$\mathrm{S} \quad=$ Setuju

$\mathrm{SS}=$ Sangat Setuju

\section{Partisipasi Masyarakat dalam Perencanaan Pembangunan}

Dari hasil kuesioner pada tabel 3 terlihat bahwa partisipasi masyarakat dalam perencanaan pembangunan cukup tinggi (gambar 1). Sebanyak $86,67 \%$ responden hadir pada Musyawarah perencanaan pembangunan desa atau yang disebut Musyawarah Nagari Rencana Kerja Pemerintah (Musnag RKP) Tahun 2019 yang dilaksanakan pada tahun 2018. Masyarakat aktif dalam mengusulkan program pembangunan $(76,67 \%)$ namun mayoritas responden tidak dilibatkan dalam pengambilan keputusan penetapan program yang masuk ke RKP Tahun 2019 (70,00\%). Selain itu, tidak semua usulan responden dimasukkan kedalam RKP Tahun 2019. Sebanyak 76,67\% responden ikut mengusulkan kegiatan dalam musyawarah desa/nagari namun hanya 33,33\% responden yang usulannya dimasukkan kedalam RKP Tahun 2019.

$$
\text { ya tidak }
$$

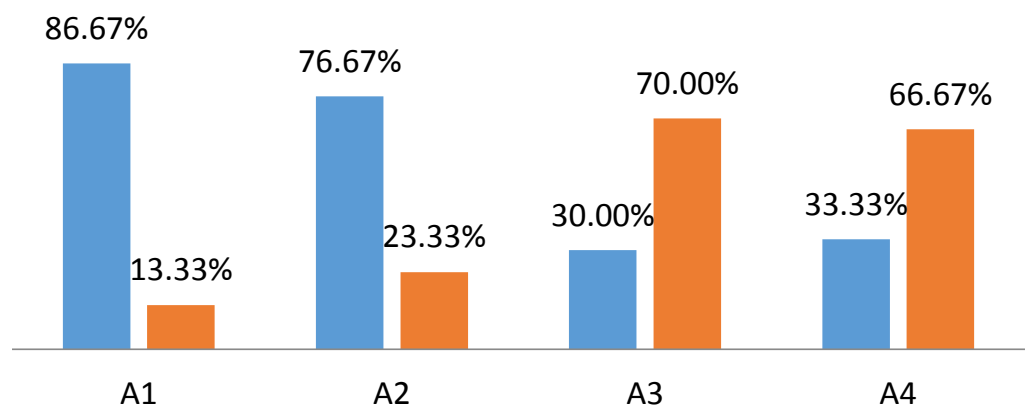

Gambar 1. Persepsi Masyarakat tentang Perencanaan Pembangunan Infrastruktur Desa 


\section{Perangkingan Kegiatan Pembangunan Infrastruktur Desa}

Dari data sebelumnya dijelaskan bahwa usulan masyarakat tidak semuanya dapat dimasukkan kedalam RKP Nagari. Semua program yang diusulkan oleh masyarakat terlebih dahulu dirangking oleh Tim Penyusun RKP Nagari. Gambar 2 berikut menjelaskan hasil kuesioner mengenai persepsi masyarakat tentang perangkingan kegiatan yang selama ini dilakukan di Nagari Inderapura Selatan.

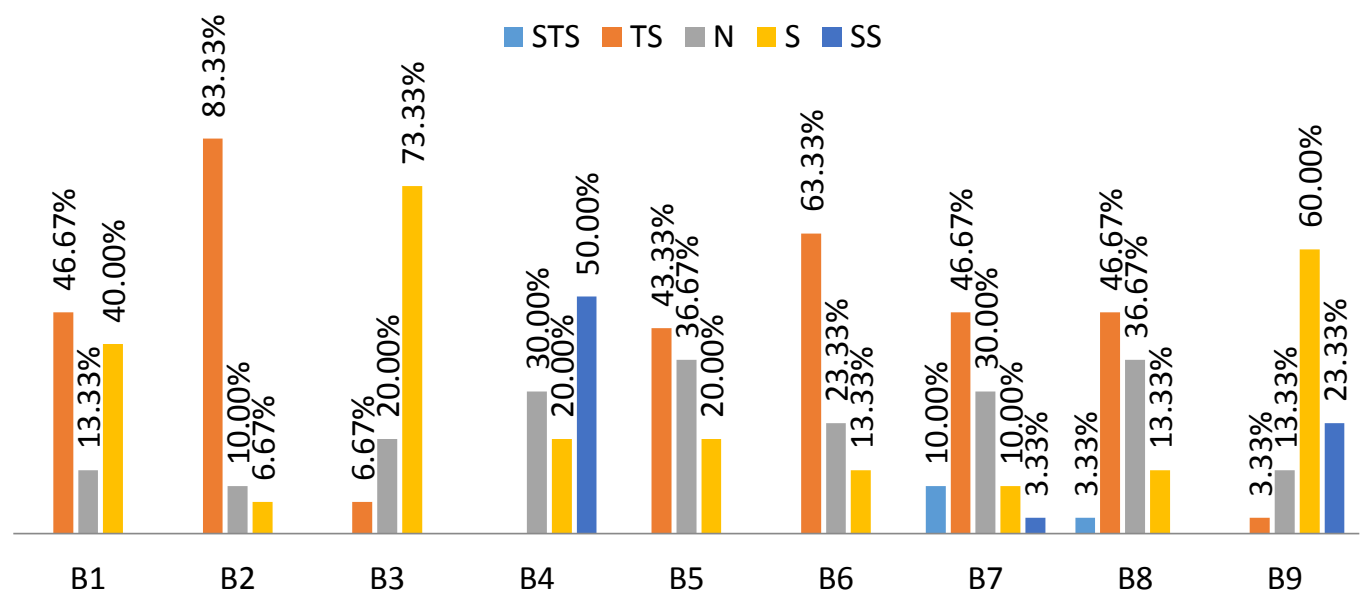

Gambar 2. Persepsi Masyarakat tentang Perangkingan Kegiatan Pembangunan Infrastruktur Desa

Pada gambar 2 terlihat bahwa jumlah responden yang menyatakan bahwa pembangunan infrastruktur nagari telah mengakomodir kebutuhan masyarakat nagari hampir berimbang dengan jumlah responden yang merasa tidak setuju dengan pernyataan tersebut. Walaupun 46,67\% responden menyatakan bahwa pembangunan infrastruktur sudah sesuai dengan kebutuhan, sebanyak 83,33\% responden merasa tidak puas dengan sistem perangkingan kegiatan yang ada sekarang dan menginginkan adanya sistem perangkingan yang lebih baik $(73,33 \%)$. Responden juga menyatakan bahwa masyarakat desa perlu terlibat langsung dalam perangkingan dan pengambilan keputusan dalam perencanaan pembangunan infrastruktur desa (20\% Setuju, 50\% Sangat Setuju), sedangkan sisanya menyatakan Netral (30\%).

Mengenai kesesuaian perangkingan kegiatan pembangunan dengan kriteria prioritas Permendes, mayoritas masyarakat menyatakan tidak setuju kecuali aspek Tipologi Desa. Masyarakat menganggap bahwa pembangunan infrastruktur desa sudah sesuai dengan Tipologi Desa namun belum semuanya berdasarkan aspek kemanfaatan $(43,33 \%)$, aspek partisipasi masyarakat $(63,33 \%)$, aspek keberlanjutan $(46,67 \%)$, dan aspek kepastian pengawasan oleh masyarakat $(46,67 \%)$.

\section{Perangkingan Kegiatan Pembangunan Infrastruktur Desa Berdasarkan Mitigasi Bencana}

Masyarakat Nagari Inderapura Selatan sangat antusias dengan pengintegrasian penanggulangan bencana kedalam perencanaan pembangunan infrastruktur desa. Hal tersebut terlihat pada gambar 3 berikut ini. Pada Pertanyaan (C1), seluruh responden menyatakan bahwa penanggulangan bencana di tingkat nagari penting untuk dilaksanakan dan perlu melibatkan masyarakat desa/nagari. 


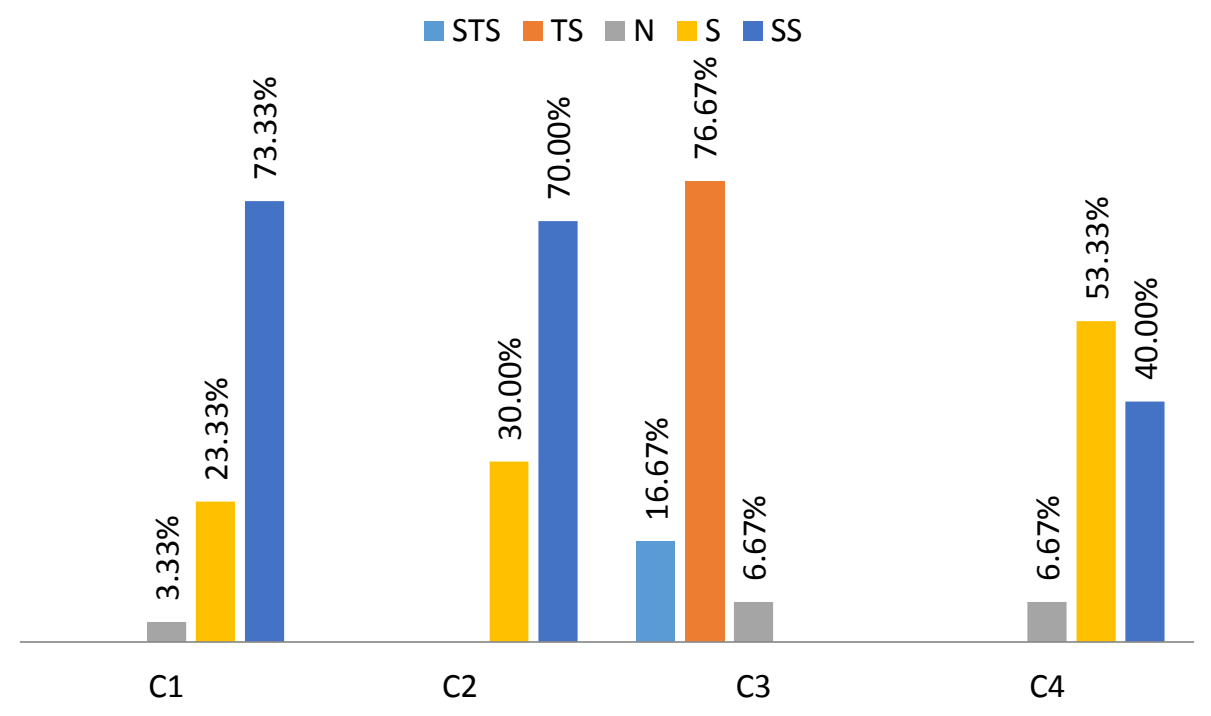

Gambar 3. Persepsi Masyarakat tentang Perangkingan Kegiatan Pembangunan Infrastruktur Desa Berbasis Mitigasi Bencana

Sebanyak 96,66\% responden menyatakan bahwa perangkingan pembangunan infrastruktur nagari Inderapura Selatan pada tahun 2019 tidak berdasarkan aspek penanggulangan bencana. Hanya 3,33\% responden yang menyatakan netral. Mayoritas responden juga menyatakan bahwa penanggulangan bencana perlu untuk berpartisipasi dalam penanggulangan bencana di Nagari serta perlu untuk memasukkan aspek penanggulangan sebagai salah satu aspek pertimbangan dalam merangking kegiatan pembangunan infrastruktur desa.

\section{KESIMPULAN}

Partisipasi masyarakat dalam musyawarah perencanaan pembangunan di Nagari Inderapura Selatan cukup tinggi. Tidak hanya dalam musyawarah, masyarakat juga menginginkan keterlibatan yang lebih besar terutama dalam perumusan prioritas program yang akan dimasukkan kedalam RKP Nagari. Perangkingan program selama ini dinilai masyarakat masih kurang mengakomodir semua aspek prioritas pembangunan infrastruktur yang dipersyaratkan permendes. Tidak hanya itu, perencanaan pembangunan selama ini belum mempertimbangkan aspek penanggulangan bencana. Padahal Mitigasi bencana merupakan hal yang penting bagi masyarakat nagari Inderapura Selatan. Masyarakat setuju untuk memasukkan aspek penanggulangan bencana dalam sistem perangkingan kegiatan pembangunan infrastruktur desa.

CATATAN. Makalah ini berupakan bagian publikasi dari Penelitian Tesis Magister (PTM); Terimakasih kepada Kemenristekdikti dan LP3M Universitas Andalas yang telah membiaya penelitian tersebut dengan nomor kontrak T/34/UN/16/17/PT.01.03/PKR-Kebencanaan/2019.

\section{DAFTAR PUSTAKA}

Perka BNPB 04/08. Peraturan Kepala Badan Nasional Penanggulangan Bencana No. 4 Tahun 2008 tentang Pedoman Penyusunan Rencana Penanggulangan Bencana.

Perka BNPB 01/12. Peraturan Kepala Badan Nasional Penanggulangan Bencana No. 1 Tahun 2012 tentang Pedoman Umum Desa/Kelurahan Tangguh Bencana.

Budiaji, W (2013). Skala Pengukuran dan Jumlah Respon Skala Likert. Jurnal Ilmu Pertanian dan Perikanan. Vol. 2, No. 2, Hal : 127-133 Desember 2013.

https://osf.io/preprints/inarxiv/k7bgy/download 
Etikan, I. et al (2015). Comparison of Convenience Sampling and Purposive Sampling. American Journal of Theoretical and Applied Statistics. Vol. 5, No. 1 : 1-4. https://www.researchgate.net/publication/304339244_Comparison_of_Convenience_Sampling and_Purposive_Sampling

Jaswadi, dkk. (2012). Tingkat Kerentanan dan Kapasitas Masyarakat Dalam Menghadapi Risiko Banjir di Kecamatan Pasarkliwon Kota Surakarta. Majalah Geografi Indonesia Vol.26, No.1, Maret 2012.

https://jurnal.ugm.ac.id/mgi/article/view/13420

Maripah. (2017). Perencanaan Pembangunan Partisipatif dalam Penyusunan Rencana Pembangunan Jangka Menengah Desa (RPJMDes) di Desa Pangkalan Baru Kecamatan Siak Hulu Kabupaten Kampar. Jom FISIP, Vol. 4, No. 2, Oktober 2017.

https://jom.unri.ac.id/index.php/JOMFSIP/article/view/15651

Nurcholis, H. et al. (2009). Perencanaan Partisipatif Pemerintah Daerah. Jakarta: Garsindo.

PerMen DPT 16/18. Peraturan Menteri Desa, Pembangunan Daerah Tertinggal, Dan Transmigrasi Republik Indonesia Nomor16 Tahun 2018 Tentang Prioritas Penggunaan Dana Desa Tahun 2019.

Prasetyo, A (2016). Pengertian Penelitian Deskriptif Kualitatif. https://www.linguistikid.com/2016/09/pengertian-penelitian-deskriptif-kualitatif.html?m=1 diakses pada 06 Oktober 2019.

Suprayitno, H. \& Soemitro, R.A.A. (2018). "Preliminary Reflexion on Basic Principle of Infrastructure Asset Management". Jurnal Manajemen Aset Infrastruktur \& Fasilitas, Vol. 2, No. 1, Maret 2018.

Suprayitno, H. \& Soemitro, R.A.A. (2019). "Pemikiran Awal tentang Prinsip Tindakan Mitigasi Preventif Resiko Bencana Alam bagi Manajemen Aset Infrastruktur \& Fasilitas". Jurnal Manajemen Aset Infrastruktur \& Fasilitas, Vol. 3, Edisi Khusus 1, Maret 2019.

Twigg, J (2004). Disaster Risk Reduction: mitigation and preparedness in development and emergency programming. Humanitarian Practice Network. London.

https://www.ifrc.org/PageFiles/95743/B.a.05.\%20Disaster\%20risk\%20reduction_\%20Good\%2

0Practice\%20Review_HPN.pdf

UU 24/17. Undang Undang Republik Indonesia No. 24 Tahun 2007 tentang Penanggulangan Bencana.

WCNDRY (1994). Guidelines for Natural Disaster Prevention, Preparedness and Mitigation. Yokohama Strategy and Plan of Action for a Safer World. World Conference on Natural Disaster Reduction Yokohama, Japan, 23-27 May 1994. https://www.ifrc.org/Docs/idrl/I248EN.pdf 